\title{
Effect of Talent Attraction on Organizational Performance: A Case of Hotels in South Rift Region, Kenya
}

\author{
Emmy Cheraisi $^{{ }^{*}} \quad$ Hillary Busolo ${ }^{1,2}$ \\ 1. Department of Business Administration, Egerton University, P.O Box 536-20115, Egerton, Kenya \\ 2. Department of Marketing, Human Resource and Hospitality Management, P.O. Box 845-50400, Busia Kenya
}

\begin{abstract}
Hotel sector in the tourism Industry is more and more treating human capital as a typical positive feature that can be leveraged to provide sustainable competitive advantage. As a consequence investors and administrators of hotels have resorted to embracing strategies geared towards talent building and relating it with their hotels. It is hoped that talented employees would enable the hotels realize their objectives. South Rift Region which was the focus of the study, exhibits diversity of star rated tourist hotels classified by Tourism Regulatory Authority. The study was conducted in two to five star hotels, within South Rift Region. This research sought to determine the effect of talent attraction on organizational performance of hotels in South Rift Region, Kenya. The study was guided by Resource Based View Theory. Given that the target population was small (40), a census survey was conducted and structured questionnaires administered to all Human Resource Managers and Hotel Managers in hotels in South Rift Region. The instrument was pilot tested to ascertain the reliability of the research instrument using Cronbach Alpha Reliability Coefficient. The reliability of the research instrument was found to be 0.946 which was considered reliable. The study employed both descriptive (frequency distributions, means and percentages) and inferential statistics. Pearson correlation coefficient and multiple Linear Regression analysis was conducted at significant level of $\alpha=0.05$. Data analysis was done with the aid of Statistical Package for Social Sciences (SPSS) version 24. The study established that talent attraction, has a positive significant effect on organizational performance of hotels in South Rift Region with correlation coefficients of $(r=0.810, p<0.05)$. The study recommends that further research could be done on Influence of Innovation Management on organizational performance.
\end{abstract}

Keywords: Talent attraction, Talent Management Practices, Organizational Performance, South Rift Region DOI: $10.7176 / \mathrm{EJBM} / 12-6-02$

Publication date: February $29^{\text {th }} 2020$

\section{Introduction}

In the contemporary difficult entrepreneurial set up, talent management practices assume a central role in driving success within organizations. The core objective of any enterprise is to meet its targets and fulfill its obligations effectively. Emerging technological advancements, evolving demographic patterns and globalization are impacting on hospitality institutions particularly in aspects of human resource (Karunathilaka, Yajid \& Khatibi, 2016). These new trends have yielded not only scarcity of workers but are also posing a threat to availability of skilled and competent human capital. For institutions to maintain a competitive edge in the contemporary fierce market place, prominence must be shifted to talent management practices. Mc Kinsey and Company (2007) described talent as the summation of a person's abilities his or her intrinsic gift, skills, knowledge, experience, intelligence, judgment, attitude, character and drive. Further it encompasses an individual's capability to gain knowledge and develop Michael et al, (2001).

According to Muntean (2014), making available the requisite number of talents in an organization has morphed into a priority issue to human resource management. Heightened local and global competition has made it mandatory for organizations to invest in efficient workforce equipped with skills to satisfy emerging local and global trends. It is also necessary for the workforce to be conversant with modernization trends within the organization.

Manpower Group India (2016) laid bare that 67\% of employers in India were experiencing complexities in staffing important positions within their institutions. Efforts were put in place to comprehend tactical impulsion of organizations in managing talent, and thereafter formulate relevant policies to be adopted by organizations. Consequently, exertions were crafted to streamline thoughts on the industry watchfulness to satisfy their talent needs. According to Manpower group Singapore (2018) 56\% of employers are unable to find the skill they had and that 62 percent of firms with 50-249 employees singled out talent scarcity and insufficient number of proficient candidates as their biggest challenge.

In Africa, a report by Price water house Coopers, indicated that talent management practices have become a priority issue due to increasing shortage of proficient workers. It further revealed that 81 percent of Chief Executive Officers interviewed intended to refocus on managing talent and 73 percent of those sampled expressed concerns that shrinking talent was a threat to growth, (Price Water House Coopers Report, 2014). Business Review Management Report, (2013) reveals that Kenya is staring at a scarcity of talented manpower in organizations. 
Talent management practices have encountered numerous challenges due to high turnover of employees poached by rival companies. It is becoming increasingly difficult to attract, retain, train and manage professional and talented employees. In Kenya for instance, early retirement has birthed scarcity of employees as there are inadequate qualified personnel to fill these positions. Talent management practices has a number of aspects which revolve around inter alia; work force planning, recruitment, selection, attraction, retention, motivation, on boarding, career management, talent development, rewards structure, innovation management and performance management (Pattanayak, 2018; Thunnissen, Boselie, \&Fruytier, 2016; Armstrong, 2014; Bersin 2006; Berger, (2004).

This study focused on talent attraction which have extensively been embraced by many scholars but are yet to be functionalized in the hotel sector. Talent attraction revolves recruitment and selection, employer branding, and job security. Employees could either be obtained internally or externally or if an organization is in a position to have the right candidates through the use of talent search matrix then it is guaranteed of competing effectively in the market (Lyria, 2013).

Organizational performance (OP) is the organizations capacity to realize its endeavors by deploying its resources in a well-organized and efficient mode. Organization performance in the Tourism Regulatory Authority sector encompasses customer satisfaction and quality of service. Customer satisfaction is premised on customer expectations and probable dimension that can be used in gauging customer satisfaction are quality, perceived reliability, extent of customer needs fulfillment, recommendation to others, closeness in relationship with constants and positioning clients, in mind (Anderson \&Sullivan 1993, Brady and Cronin, 2001 Kottler \& Armstrong 2007). Quality of service is the extent to which customers' perception of service meet and exceed their expectation (Woodwall, 2001). Quality of service encompass inter alia: communication, accessibility, reliability, timeliness, assurance, empathy and awareness of consumer's needs (Rumezani, 2015).

\subsection{Statement of the Problem}

Talent Management practices are becoming more important in organizations today as Managers strive with attracting talented employees in order to achieve their objectives (Keoye, 2014; Skuza, Scullion, \& McDonnell, 2013; Boston Consulting Group, 2007). Recruitment models have been modified to attract talented individuals into organizations, managers are finding it difficult to retain talented employees and developing talent is posing its own challenges (Armstrong, 2014). All these have an ultimate intention of improving organizational performance. Moreover, research on organization performance has pointed more on financial organizational performance ignoring non-financial performance. Therefore, this study focused more on non-financial organizational performance. The hotel industry in Kenya has employed talent management practices (Kichuk, 2017; O'Halloran, 2012, Robinson et al. 2014), by attracting, and nurturing talent in employees over time, though with different levels of success (Derry, 2015; Kleinman, 2016; Capelli and Keller 2014; Armstrong 2014). Hotels on the other hand have experienced different levels of performance advanced by inability of hotel management to attract talented employees. Moreover, the effect of talent attraction has not been sufficiently investigated in hotel industry especially in South Rift Region. Therefore, this study sought to investigate the effect of talent attraction on organizational performance of hotels in South Rift Region.

\subsection{Purpose and Objective of the Study}

To determine the effect of talent attraction on organizational performance of hotels in South Rift Region, Kenya.

\subsection{Research hypotheses}

$\mathbf{H}_{01}$ : There is no significance difference in effect of talent attraction on organizational performance of hotels in South Rift Region, Kenya.

\subsection{LITERATURE REVIEW \\ 2.1 Theoretical Framework}

The study was guided by Resource Base View Theory. The Resource Based View Theory as a strategy to attain competitive advantage and performance emerged in 1980s and 1990s, after the major works published by Wernerfelt, Prahalad, Hamel, and Barney. This theory asserts that the resources possessed by a firm are the major determinants of its performance. Resource Based View in Human resource management places more emphasis on human aspect of the job and deemed talented personnel as a viable advantage of organization (Barney, 1991). Resource Based View argues that firms should look inside the organization to find the sources of competitive advantage instead of focusing at competitive environment. The Resource Based View provides an avenue for organizations to plan and executes their organizational strategy by examining the position of their internal resources. Human capital is one of the most important internal resources in organizations. It is of paramount importance to invest in human capital which is a value created resource for the organizations as in the long run it provides high performance. Talent managment which is an intangible resource is considered more important and 
critical in attaining good performance. The Resource Based Theory is premised on the assumption that firms are fundamentally heterogeneous regarding their resources and internal competencies. It tackles the challenges of how firms can exploit their internal resources and capabilities to obtain sustained competitive advantages and performance (Barney, 1991; Hamel and Prahalad, 1994).

The Resources based view of the firm proposes that an organization's human capital management practices can give significantly to sustaining competitive advantage and performance by attracting and creating specific skills, knowledge, that are difficult to duplicate within a firm (Afiouni 2007). In other words, by creating resource diversity through improving skills, and knowledge, that could create and maintain sustainable competitive advantage and performance. Organization must not only be able to create knowledge within their organization but they must also expose themselves to getting new ideas by recruiting employees from both internal and external sources and developing by providing regular training to gain more skills, to increase competence, leading to high performance. This will also prevent rigidity, and encourage innovative habits and helps to retain workforce for long (Garavan, 2001). The RBV expounds value creation superiority, competitive advantages and possession of valuable resources which are (talents). The RBV argues that valuable resources have to be secured to ensure competitive advantage and growth of the organization. Organization performance improves if resources are cared for, nurtured and protected. When an organization identifies talents which can provide it with competitive advantage, it will acquire certainty to fulfill its objectives and satisfy customers which in turn will improve performance. The enhanced performance will be sustained since the organization will also secure the talents by ensuring that they are not taken away (Armstrong et al.2010). This theory is fundamental to this study since it will enable organizations to identify the valuable resources which are talents, nurture and protect them from competitor's to ensure competitive advantage and therefore increase organizational performance.

\subsection{Talent Attraction and Organizational Performance}

Michington, (2010), indicated that in an era where skills and knowledge of employees gives an organization competitive advantage, the importance of procuring and retaining the talented employees cannot be ignored. Recruitment is the process of searching for prospective employees and stimulating them to apply for jobs in the organization. Selection may be defined as the process by which the organization chooses from among the applicants, those people whom they feel would best meet the job requirement, considering current environmental condition (Karthiuga, Karthi \& Balaishwarya 2015). Recruitment and selection has become ever more important as organizations increasingly regard their workforce as a source of competitive advantage (Ntiamoah, 2014). Recruitment and selection requires that organizations use various techniques of selecting the right talent that reflects the culture and value of that particular organization (Armstrong, 2006).

According to Carroll, Marchington, Earshaw \& Taylor (2018) organizations that recruited internally usually got a raw deal because the internal employees did not add anything new to the organizations. For an organization to be competitive, it has to amalgamate ideas and talents from within and outside the organization as this would create diversity and synergy within the company. According to Branham (2012), many organizations recruit externally prior to looking at inside talent due to the reasons such as corporate culture and managers struggling to retain the best performing individuals and not losing them to other managers. The talent managing organizations will have pursued its employee's capacity and career aspirations so that it can encourage internal career movement. As the profile of workforce is changing; the young force is generally regarded as less committed to the organization than their senior colleagues (Uysal, 2015). This has presented complexities to the human resource in recruiting and selecting the right talent to fit into the right job.

Gamage (2014), indicates that there is a helpful and noteworthy affiliation between recruitment and selection and the performance of an organization. The selection procedures inform who to be employed. If appropriately taken into account it will recognize proficient applicants and precisely place them to relevant job. Deploying efficient selection method will improve prospects of a right individual being picked to fill a slot. Output is improved when the best candidates are picked for the job.

Employer branding considers a set of actions which enables an organization to capture attention of prospective employees. It portrays an organization as enticing to job seekers hence an organization expends less energy in developing its talents. Attractiveness of an organization arms it with a competitive gain (Yagub \& Khan, 2011). According to Iles and Preece (2010) employees are duty-bound to brand themselves as employers of choice by attaining a good image with regard to employee working conditions and rewards. Sokro, (2012) studied the impact of employee branding on employee attraction and retention found out branding as a main instrument for organizations to attract quality employees in their organizations. CIPD (2013) report asserts that best talent is attracted through branding. It further established nearly three-quarters of organizations initiated attempts aimed at improve branding. Botha and Swarth (2011), found out in their study that employers who attracted talented employees had recognized target group needs first. Further statement of employer brand message a vital factor that determined whether the right job seekers would be attracted to the organization.

Adebayo and Lucky (2012) established that, owing to economic factors job security was a critical issue in 
employee and organization favorite list. Thus, it is now among the most key and significant factors in the employee preference list as well as the organization (Schappel, 2012; KPMG, 2010). About 75\% of the employees globally, preferred to keep their jobs compared to other factors in their preference list (Towers Watson, 2010). This demonstrates equals in importance the employees' salary and healthcare (KPMG, 2010). Presently, the greatest aspiration of every workers is to retain their jobs for as long as they wish. Hence, job security has morphed into a great determinant and key element influencing an employee's decision on whether to join an organization or not (Towers Watson, 2010). The key challenge facing the organization is not just to employ and retain workers but to guarantee employees that their jobs are safe for as long as they wish. Wang, Lu, \& Siu (2015) study on the association between job insecurity and performance established that heightened feelings of job insecurity were correlated with low levels of job performance. This was in contrast for a workforce in organizations with high levels of organizational justice. Organizational fairness revolves around the policies and procedures put in place to make employees feel as though they are treated fairly.

\subsection{Conceptual Framework}

\section{Independent variable}

\section{Talent attraction}

-Recruitment and Selection

- Employer Branding

Job security

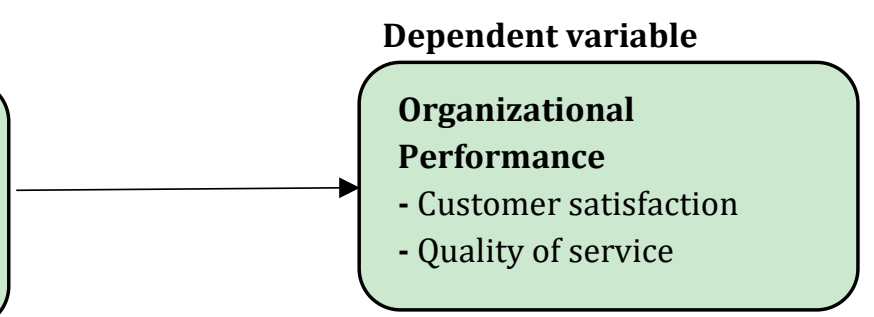

Source: Researcher (2020)

\subsection{METHODOLOGY}

This study adopted cross sectional survey research design. The target population of the study comprised of forty (40), two to five star tourist hotels in South Rift Region as per classification by The Tourism Regulatory Authority. A censuses method was conducted whereby all (40) HR Managers and Manager participated in the study. Questionnaires were distributed to the respondents through drop and pick later method. A total of 38 questionnaires were successfully filled giving a response rate of $95 \%$.

\subsection{RESULTS AND FINDINGS}

\subsection{Descriptive Statistics}

Descriptive statistical analysis was used to analyze elements of talent attraction. In reference scaling (Likert scale) was used in the study design, 5 represented strongly agree, 4 represented agree, 3 represented neutral, 2 represented disagree and 1 represented strongly disagree, therefore strongly disagree (1) was minimum (Min), strongly agree (5) was maximum (Max). The mean was analyzed based on the respondent's choices scaled between strongly agree and strongly disagree as indicated in table 1

\section{Table 1: Elements of Talent Attraction}

\begin{tabular}{|c|c|c|c|c|}
\hline \multirow{2}{*}{$\begin{array}{l}\text { Elements of Talent Attraction } \\
\text { We have internal recruitment policy that helps to raise the loyalty of our employees }\end{array}$} & \multicolumn{3}{|c|}{ N MinMaxMean } & \multirow{2}{*}{$\begin{array}{l}\text { Std. } \\
\text { Dev. } \\
.528\end{array}$} \\
\hline & 383 & 5 & & \\
\hline $\begin{array}{l}\text { Our internal recruitment policy is done fairly which has boosted morale of o } \\
\text { employees }\end{array}$ & ur38 3 & 5 & & .578 \\
\hline ng selection of its candidates selects both internally and externall & to38 2 & 5 & 4.42 & .826 \\
\hline & 382 & 5 & & .820 \\
\hline ecurity to its employees & 382 & 5 & 4.00 & .805 \\
\hline Valid N (listwise) & 38 & & & \\
\hline
\end{tabular}

According to the findings of the study in table 1, most aspects had their mean approximately 4 (agree) showing that most respondents agreed with most elements of level of talent attraction. This could be attributed to the strategies put in place by the hotel management to attract talented employees. 
Table 2: Elements of Customer Satisfaction as an Indicator of Organizational Performance

Std.

Elements of Customer Satisfaction

N MinMaxMeanDev.

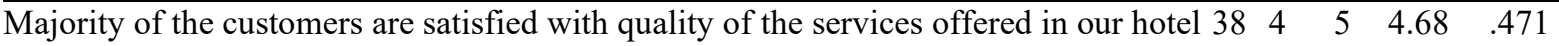

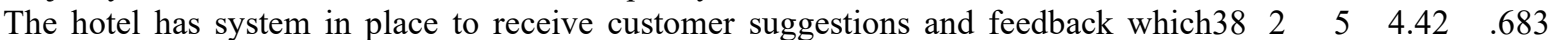

satisfies our customers

Our customers find our services more reliable hence they get satisfied

$\begin{array}{lllll}38 & 3 & 5 & 4.47 & .557\end{array}$

$\begin{array}{llllll}\text { Our customers are satisfied with the branding of our hotel } & 38 & 3 & 5 & 4.13 & .57\end{array}$

I am able to interact effectively with clients to understand their requirements hence able38 $\quad \begin{array}{lllll}4 & 5 & 4.58 & .500\end{array}$

to satisfy our customers

Valid N (listwise)

38

According to the findings of the study in table 2 the respondents strongly agreed that, majority of the customers are satisfied with quality of the services offered in their respective hotels and possess the ability to interact effectively with their clients to understand their requirements hence able to satisfy them with mean inclined towards 5(strongly agree). Moreover, the respondents agreed that their hotels has system in place to receive customer suggestions and feedback which enhances customer satisfaction and their customers are satisfied with the branding of the hotel with mean inclined towards 4(agree).

Table 3: Elements of Quality of Service as an Indicator of Organizational Performance

Elements of Quality of Service

Std.

N MinMaxMeanDev

\begin{tabular}{lllllll}
\hline Involvement of employees in decision making in the hotel has improved quality of38 & 2 & 5 & 4.03 & .788
\end{tabular} service

Employees are given incentives that enables them to provide quality service

$\begin{array}{lllll}38 & 2 & 5 & 3.95 & .804\end{array}$

There is effective service delivery in our hotel

$\begin{array}{lllll}38 & 3 & 5 & 4.39 & .638\end{array}$

The quality of services offered in our hotel remains constant hence they are reliable $\quad \begin{array}{llllll}38 & 3 & 5 & 4.42 & .552\end{array}$

Our services are offered timely, with no delay

$\begin{array}{lllll}38 & 3 & 5 & 4.42 & .552 \\ 38 & 4 & 5 & 4.42 & .500\end{array}$

Valid N (listwise)

38

According to the findings of the study in table 3, most elements had their mean inclined towards 4(agree) showing that most respondents agreed with most elements of quality of service. This could be attributed to the fact that quality of service has a direct link to customer satisfaction.

\subsection{Effect of Talent Attraction on Organizational Performance of Hotels in South Rift Region, Kenya}

The first hypothesis of this study was to test whether there is significance difference in effect of talent attraction on organizational performance of hotels in South Rift Region, Kenya. The study used Pearson moment correlation to establish the strength, direction and significance of the relationship that exist between talent attraction and organizational performance of hotels.

Table 4.1: Correlation between Talent Attraction and Organizational Performance of Hotels

\begin{tabular}{llc}
\hline & & Organizational performance \\
\hline Talent attraction & Pearson Correlation & $0.810^{* *}$ \\
& Sig. (2-tailed) & 0.000 \\
& $\mathrm{~N}$ & 38 \\
\hline
\end{tabular}

** Correlation is significant at the 0.05 level (2-tailed).

The study further used linear regression analysis to determine the effect of talent attraction on organizational performance of hotels in South Rift Region, Kenya using the model as follows:

$\mathrm{Y}=\mathrm{B}_{0}+\beta_{1} \mathrm{TA}+\varepsilon$

Where $\mathrm{Y}=$ Organizational Performance of Hotels in South Rift Region

$\mathrm{B}_{0}=$ Constant

$\beta_{1}=$ Régression coefficient

$\mathrm{TA}=$ Talent Attraction

$\varepsilon=$ Error term 
Table 4.2: Results of Linear Regression Analysis Determining the Effect of Talent Attraction on Organizational Performance of Hotels

Model Summary

\begin{tabular}{llllll}
\hline Model & $\mathrm{R}$ & R Square & Adjusted R Square & $\begin{array}{l}\text { Std. Error of } \\
\text { Estimate }\end{array}$ & the \\
\hline 1 & $0.810 \mathrm{a}$ & 0.657 & 0.647 & 0.22530 & 2.126 \\
\hline
\end{tabular}

a. Predictors: (Constant), Talent attraction

b. Dependent Variable: Organizational performance

\begin{tabular}{llllllll}
\hline \multicolumn{7}{c}{ ANOVA } \\
\hline Model & & Sum of Squares & Df & Mean Square & F & Sig. \\
\hline & Regression & 3.493 & 1 & 3.493 & 68.815 & $0.000 \mathrm{~b}$ \\
\cline { 2 - 7 } & Residual & 1.827 & 36 & 0.051 & & \\
\hline & Total & 5.320 & 37 & & & \\
\hline
\end{tabular}

a. Dependent Variable: Organizational performance

b. Predictors: (Constant), Talent attraction

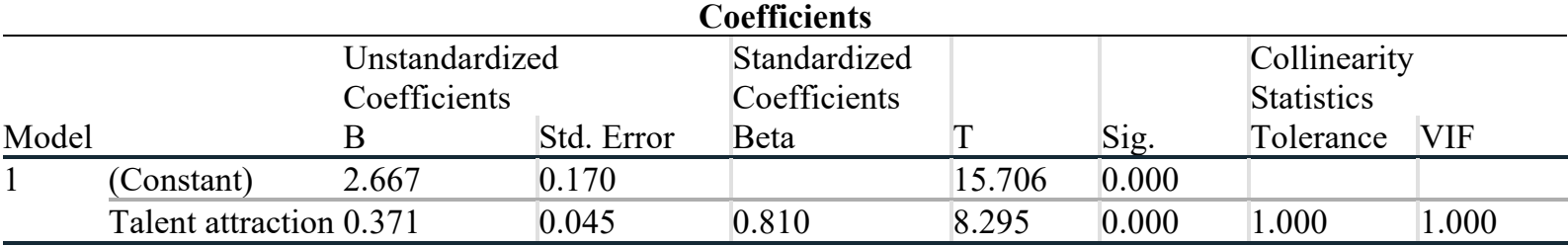

a. Dependent Variable: Organizational performance

According to the regression results in table 4.2, the linear regression model specifies that talent attraction accounted for $65.7 \%\left(\mathrm{R}^{2}=0.657\right)$ of organizational performance of hotels in South Rift Region. Therefore $34.3 \%$ of the variance in organization performance was explained by other factors not in the study. The F statistic (68.815) shows the fitness of the linear regression, which means talent attraction is a significant predictor of organization performance. The unstandardized beta coefficients indicate that talent attraction $(\beta=0.371, p<0.05$ was a strong predictor of organizational performance of hotels in South Rift Region, Kenya. Therefore, the linear regression results in table 4.2 indicate that that talent attraction has a statistical positive significant effect on organizational performance of hotels in South Rift Region, Kenya. Consequently, the null hypothesis $(\mathrm{H} 0=0)$ which stated that 'there is no statistically significance difference in effect of talent attraction on organizational performance of hotels in South Rift Region, Kenya' was rejected and the alternative hypothesis $(\mathrm{H} 1 \neq 0)$ which states that 'there is statistically significance difference in effect of talent attraction on organizational performance of hotels in South Rift Region, Kenya.' was accepted. This suggests that organization performance of hotels is enhanced through talent attraction. The findings of the study agree with studies done by (Kelly, 2013; Rop, 2015). From table 4.2, the Durbin-Watson statistic is 2.126 which is between 1.5 and 2.5 and therefore the data was not auto correlated. Moreover, the table 4.2 indicates that there was no multi-collinearity as shown by tolerance $(\mathrm{T}>0.2)$ and Variance Inflation Factor $(\mathrm{VIF}<10)$.

Linear Regression Model

$\mathrm{Y}=2.667+0.371 \mathrm{TA}+\varepsilon$

Interpretation

When there is $1 \%$ increase in talent attraction, organizational performance of hotels in South Rift Region will increase by $0.371 \%$. The linear regression model above specifies that the talent attraction has a positive effect on organizational performance of hotels in South Rift Region.

\subsection{Summary of the Study Findings}

The main objective of the study was to determine the effect of talent attraction on organizational performance of hotels in South Rift Region, Kenya. The findings of the study revealed that talent attraction was a significant determinant of organizational performance of hotels in South Rift Region, Kenya.

\subsubsection{Talent Attraction and Organizational Performance of Hotels}

Based on the findings of the study, it was established that majority of the respondents agreed that internal recruitment policy is done fairly and candidates are selected both internally and externally during recruitment to enable it to get the best talent. In broad-spectrum the results revealed a strong statistically significant positive relationship between talent attraction and organizational performance of hotels, specified by strong positive significant correlation of $81 \%$. This confirms the positive significant effect of talent attraction on organizational performance of hotels in South Rift Region, Kenya. 


\subsection{Conclusion}

The study concludes that Talent attraction has statistically positive effect on organizational performance of hotels in South Rift Region. This suggests that organizations are likely to enjoy significant improved organization performance as a results of adoption of talent attraction practices which includes, recruitment and selection, employer branding and provision of secure working environment.

The study concludes that hotels should develop policies through which employees are identified and selected. This can be enhanced by the hotels ability to monitor and absorb new employees both internally and externally so as to attract the most excellent talent.

\subsection{Recommendations for Further Research}

The purpose of the study was to determine the effect of talent attraction on organizational performance of hotels in South Rift Region, Kenya. This research selectively captured effect of talent attraction on organizational performance of hotels in South Rift Region only. Therefore, further research can be done to capture other organizations in South Rift Region and other regions to establish whether the findings will be replicated. Further research could also be done on Influence of Innovation Management on organizational performance.

\section{References}

Adebayo, O.I. \& Lucky, E., (2012). Entrepreneurship Development and National Job Security. Proceedings of the Laspotech SM National Conference on National Job Security Main Auditorium, June 25-26, 2012, Isolo Campus, Lagos, Nigeria.

Armstrong, M. (2011). A Handbook of Human Resource Management Practices (10 ${ }^{\text {th }}$ Ed). London: Kogan Page Ltd.

Armstrong, M. (2014).A Handbook of Human Resource Management Practices (13th ed). London \& Philadelphia: Kogan Page Limited.

Armstrong, M., (1995).A Handbook of Personnel Management Practices. Kogan Page Limited London.

Armstrong, M., (2006). Human Resource Management. Practice 10th ed. Kogan Page. London and Philadelphia.

Ashridge Consulting (2007). Talent Management: Maximizing Talent for Business Performance, Chartered Institute of Management.www.ashridge.org.uk

Bersin, Josh (2006). Talent Management, What is it, Why Now. Journal of World Business, 1-5.

Boston Consulting Group. (2007). The Future of HR: Key Challenges Through 2015. Dusseldorf: Boston Consulting Group.

Botha, A., Bussin, M. \&Swardt, L. (2011). An Employer Brand Predictive Model for Talent Attraction and Retention. Open Journals, 388.

Business Management Review, (2013). Challenges Facing Management in Kenya. Retrieved $19^{\text {th }}$ May 2013 from $\mathrm{http}$ ///businessreviewkenya.com/challenges-facingmanagement-in-kenya/.

Cooper, D., \& Schindler P., (2014). Business Research Methods. Mc Graw Hill Education.

Derry, M. (2015). Talent Management Work-Life Balance and Retention Strategies. International Journal of Contemporary Hospitality Management.

Devi S., (2017). Impact of Talent Management on Organizational Performance: Role of Employee Engagement. International Journal of Management Studies, 2249-0302.

Devine, M.P. (2008) Talent Management in Public Sector Ashridge Business School. United, Kingdom.

Fitzgerald, L., Johnston, R., Brignall, S., Silvestro, R. and Voss, C. (1991), Performance Measurement in Service Businesses, CIMA, London.

Gamage, A. S. (2014). Recruitment and Selection Practices in Manufacturing SMEs in Japan: An analysis of the Link with Business Performance. Ruhuna Journal of Management and Finance, 1(1), 37-52

Gara, R. (2007). Talent Management in Egypt. Paper Prepared for Presentation at the Global Talent Management Centre.

Hartman, E., Faisel E. \& Schober H., (2010) Talent Management of Western MNCs in China; Balancing Global Integration and Local Responsive. Journal of World Business 45(2)169-178

Horvathova P. \& Mikusova M. (2011). Holton, E. F. (1996). New employee development: A Review and Reconceptualization. Human Resource Development Quarterly, 7(3), 33.

Hughes, J. C., \& Murray, W. C. (2018). 7. Evolving conceptions of talent management: a roadmap for hospitality and tourism. Handbook of Human Resource Management in the Tourism and Hospitality Industries, 153.

Hughes, R. (2015). Mental health and stress, Return to Work and Rehabilitation Published by British Association for Counselling \& Psychotherapy.

Kaewsaeng-on R., Kane J.K., and Vundla, S. (2015). Talent - Its Application to the Thai Hospitality Industry. International Journal of Innovation, Management and Technology, Vol. 6, No. 6.

Karthiuga G., Karthi R., \& Balaishwarya P., (2015). Recruitment and Selection Process. International Journal of Scientific and Research Publication. Vol. 5 Issue 4 ISSN 2250-4153 
Karunathilaka, K. G. G. S., Yajid, M. S. A. \&Khatibi, A., (2016). A Global Talent Management Strategies and Opportunities for the Performance of Private Sector Organizations in Srilanka. International Journal of Academic Research and Reflection, pp. Vol. 4, No. 2, 65-77.

Keoye, K.N., (2014). Examining the Effects of Talent management on Organizational Performance: A Case of Comply Limited Nakuru. Master of Business Administration, Human Resource Management. Kenyatta University.

Kichuk A., (2017). Understanding Talent Management in the Hotel Sector: Employees' Narratives of Personal Career Development. A Thesis Submitted in Partial Fulfillment of The Requirements of Bournemouth University for The Degree of Doctor of Philosophy.

KPMG, 2010. April 2010: Recent study reveals job security more important than pay and benefits for university students.

Kumar, S, \& Kavita, K. (2014). Factors Affecting Talent Management Practices. A Review. Research Paper Commerce, Vol. 3 Issue 11

Lewin L.A., (2014). Cross Sectional Studies. University of Dundee, Scotland, United Kingdom.

Lyria R.K., Namusonge G.S., \& Kabare K., (2017). The Effect of Talent Attraction n Organizational Performance of Firms Listed in the Nairobi Securities Exchange. Journal of Human Resource and Leadership Management. Gower, United States.

Lyria, R., (2013). Effect of Talent Management on Organizational Performance in Companies Listed in Nairobi Security Exchange Kenya. Doctor of Philosophy in Human Resource Management, Jomo Kenyatta University of Agriculture and Technology.

Manpower Group Singapore (2018). Talent Shortage Survey. Solving the Talent Shortage. Singapore.

Mugenda \& Mugenda A.G., (2012). Research Methods Dictionary. Nairobi ACTS Press.

Mugenda, O.M., and Mugenda, A. G., (2003). Research Methods: Quantitative and Qualitative Approaches. Nairobi, ACTS Press.

Michaels, E., Handfield-Jones, H. i Axelrod, B. (2001). The war for talent. Boston: Harvard Business School Press.

O‘Halloran, P. (2012). Performance pay. Effect of Compensation Strategy on Corporate Performance employee turnover. Journal of Economic Studies, 39 (6), 653-674.

Onwuka, M. Ugwu, E. \& Kekecho, E. (2015). The Relationship between Talent Management and Employee Performance in Nigeria Public Sector: A Study of Selected Firms in Delta State. Journals of Economics, Commerce and Management, 3(5)1581-1592.

Pattanayak, B. (2018). Human Resource Management, $5^{\text {th }}$ Edition. PHI Learning Private Limited. Delhi.

Price Water House Coopers (2014). People Strategy for the Digital age: $18^{\text {th }}$ Annual Global CEO Survey.

Robinson, R.N.S., Kralj, A., Solnet, D.J., Goh, E., and Callan, V., (2014). Thinking job embeddedness not turnover: towards a better understanding of frontline hotel worker retention. International Journal of Hospitality Management 36, 101-109.

Sareen, P., \& Mishra, S. (2016). A Study of Talent Management and Its Impact on Performance of Organizations. Journal of Business Management, Vol. 18, Issue 12, pp. 66-73.

Schappel, C., (2012). Top Ten Job factors that Attract, retain Employees. Secondary School Teachers in Eldoret Municipality Kenya. International Journal of Scientific and Research Publications, Volume 3, Issue 6, 22503150.

Schuler, R. S. (2015). The 5-C Framework for Managing Talent. Organizational Dynamics, 1(44), 47-56.

Sindiga, I. (2018). Tourism and African Development: Change and Challenge of Tourism in Kenya. Routledge.

Sokro, E. (2012). Impact of Employer Branding on Employee Attraction and Retention. European Journal of Business and Management 4(18) 164-173.

Stahl, G.K. Bjorkman, I., Farndale E., Morris, S. S., Paauwe, J., Stiles, P., \& Wright, P.M. (2007). Global Talent Management: How leading multinationals build and sustain their talent pipeline. INSEAD Faculty and Research Working Papers, 24.

Super D.E. (1990). A Life Span, Life Space Approach to Career Management. Applying Contemporary Theories to Practice. San Francisco, CA, US: Jossey-Bass.

Thunnissen, M., Boselie, P., and Fruytier, B. (2013). Talent Management and the Relevance of Context: Towards A Pluralistic Approach. Human Resource Management Review, 23(4), 326-336.

Uysal, S., Sahin, K. Cetin, G., \&IstanbulluDincer F., (2015). Career Management in Hospitality: The Case of Four and Five Star Hotels in Instabul.

Wang H.J., Lu Q.C. \& Siu, L.O. (2015). Fairness, Human Resources, Job performance, Motivation, Organizational Justice, Trust. Journal of Applied Psychology.

Yagub \& Khan (2011). The Role of Employer Branding and Talent Management for Organizational Attractiveness. Far East Journal of Psychology and Business, Far East Research Centre, Vol. 5(5) pages 57-65. 